\title{
Global pipelines: profiling successful SME exporters within the Australian wine industry
}

\author{
David Aylward
}

\author{
Faculty of Commerce \\ University of Wollongong \\ NSW 2522, Australia \\ E-mail: david_aylward@uow.edu.au
}

\begin{abstract}
Increasingly, entire industry sectors and individual firms are re-orienting their business strategies to align with the demands of rapid globalisation. Sustainable export mechanisms are becoming an integral component of these strategies. Small, medium and large firms are focusing more than ever on marketing goals, branding, distribution channels and production quality in order to address the growing opportunities and challenges of this globalisation. An industry in which firms are responding effectively to these opportunities and challenges is the Australian wine industry. In terms of export growth, intensity, diversity and sustainability, this industry is increasingly seen as a template for others.

Using empirical data derived from a survey and in-depth interviews with Australian wine SMEs this article attempts to provide a set of characteristics common to successful exporters. Such characteristics, based on core export indicators and management attributes may help to provide lessons for firms in general and wine firms in particular.
\end{abstract}

Keywords: wine industry; exporting; SMEs; clusters; globalisation.

Reference to this paper should be made as follows: Aylward, D. (2006) 'Global pipelines: profiling successful SME exporters within the Australian wine industry’, Int. J. Technology, Policy and Management, Vol. 6, No. 1, pp.49-65.

Biographical notes: David Aylward is a Research Manager for the Faculty of Commerce at the University of Wollongong and a Research Fellow in the Centre for Governance and Innovation in Business. David has been studying innovation networks, clusters, diffusion and uptake in industry and particularly the wine industry for a number of years. He has written extensively in both scholarly and industry journals and has established a research programme in this area within the Centre for Governance and Innovation in Business.

\section{The Australian wine industry - background}

The Australian wine industry, like most New World wine industries, had rather inauspicious beginnings. Wine grapes were introduced to the new colony under Governor Phillip in the 1790s, with the first plantations in western Sydney, New South Wales. By 1795 the first vineyard had produced 410 litres of wine (Beeston, 1994). For the next half-century plantings were sporadic until a new immigrant, James Busby, undertook 
serious plantings in the Hunter Valley. Plantings in Victoria, South Australia and Western Australia soon followed and the Australian wine landscape began its slow and often troubled evolution. In the latter half of the 19th century the young industry was beset by a number of major problems, the main one being the lack of any real domestic market. Compounding this was an apparent inability to access international markets due to Australia's reputation as a 'backwater colony' and the lack of recognition accorded to its wines (Faith, 2002).

It was not until federation in 1901 that Australian wine-makers looked forward with any degree of optimism. With federation came the removal of the debilitating trade barriers between states. Wine, at last, appeared to be a viable commodity. Until the early 1980s, however, Australia was still seen by much of the world as a bulk wine supplier, with little sophistication and only bland products to offer. The proliferation of vineyards in the 1980s and 1990s and the renewed focus on international markets, with the requisite demand for quality at last brought fundamental changes to the way wine was grown, made and marketed (Faith, 2002).

The Australian wine industry today is at the forefront of a changing international wine landscape, having sacrificed tradition for innovation and growth. As a result, it has transformed itself from a cottage industry to an international success story. The industry now has 2000 wineries, with 164181 hectares under vine crushing 1.86 million tonnes a year, with exports of $\$ 2.75$ million (Winetitles, 2005). Grape varieties include Chardonnay (42.5\% of white varieties), Marsanne, Reisling, Sauvignon Blanc, Viognier, Shiraz, Cabernet Sauvignon, Tempranillo, Petit Verdfot and Sangiovese. Red varieties now account for $59.5 \%$ of those under vine (Winetitles, 2005). Wine production by state is: South Australia with 48.7\%, New South Wales 31.3\%, Victoria 15.6\%, Western Australia 3.9\%, Tasmania 0.17\% and Queensland 0.05\% (Winetitles, 2005). The industry is now the world's 7th largest producer and 4th largest exporter.

\section{Why profile Australian wine exporters?}

As the international wine landscape continues its transformation, the production, distribution and marketing of wine no longer remains the geographic and cultural preserve of European producers. Over the past two decades wine has been democratised by the production and export leadership of New World industries such as Australia, California, South Africa, New Zealand and to some extent, Chile and Argentina. These consumer-driven industries are increasingly taking market share from the Old World, producer-driven industries at each of the highest demand price-points. In two of the world's major markets - the UK and the USA branded and premium wine labels are now dominated by New World industries. For example, in the UK in March 2004, eight of the top ten selling wines were from the New World. This is almost a complete reversal of the situation of less than a decade ago. If intra-European trade is removed from wine export data, we see that between 1987 and 1997, European producers' share of global exports fell from $82 \%$ to $59 \%$. Over the same period, New World exports rose from approximately 9\% to 28\% (Anderson, 2000). Between 1997 and 2004, this reversal of trade has continued to escalate. 
When we look more closely at this New World challenge, the export leadership of Australia becomes apparent. For example, in terms of export intensity, New Zealand, Californian and South African exports fall substantially behind those of Australia with 25.8\%, 15\% and 24.7\% respectively (Winetitles, 2005). ${ }^{1,2}$ Australia's export intensity is approximately 50\% (Winetitles, 2005). The number of markets to which Australian firms currently export is more than double that of most other New World exporters. Australia is now the world's 4th largest exporter, behind Italy, France and Spain, or the world's 2nd largest exporter behind Italy, if EU trade is excluded (Anderson, 2000). Over the past decade the Australian wine industry has shown an export growth of approximately $1200 \%$ in value terms (Winetitles, 2005). This rate is more than three times that of the global average (Anderson, 2000).

As an indication of the rise in export quality, Australia's average wine export price between 1992 and 1997 rose 52\% compared to a global average of 20\% (Anderson, 2000). A major difference, however, between Australia and its New World competitors is that, over the past decade, Australia's exports grew in parallel with its production growth. This was part of deliberate and specific strategies embodied within the industry's 2025 vision. In contrast, North America's export growth was derived from slower production, with no growth in domestic consumption. In other New World industries a decline in consumption was alone responsible for the dramatic growth in exports (Anderson, 2000).

In terms of best-practice export models, therefore, it appears that Australian firms provide for the most appropriate sample group.

\section{Current internationalisation literature}

To date, the literature on export performance measures, primarily from a strategic management perspective, has been inadequate. Issues most commonly dealt with include export planning (Wang and Olsen, 2002), global export challenges (Leonidou, 2004; Yetton et al., 1991), market adaptation practices (Ogunmokun and Wong, 2004), general internationalisation principles (Spence, 2003), and strategic decision-making (Darling and Taylor, 2003). Less commonly does the literature deal with specific firm-based export performance, particularly in an Australian context. Nor does it adequately address the sustainability of firm-based exports within industry networks or clusters.

Currently, within management disciplines as well as marketing and economics there is also a substantial debate taking place between the export stage theorists, who believe that a firm's internationalisation is an incremental process, evolving with the maturity of the firm, and the 'anti-stage theorists' who point to 'Born Global' exporters as evidence that substantial internationalisation can take place at any time in a firm's maturity (Moen and Servais, 2002; Wolff and Pett, 2000; Voerman, 2003). Yet despite this prolonged debate, very few commentators have focused on what the users themselves are increasingly identifying as important - export sustainability.

A number of empirical studies carried out by the author and others suggest that from a user perspective, that is, the firms themselves, sustainability of exports is one of the most critical factors in firm operation (Aylward and Turpin, 2003; Aylward, 2003; 2004a; 2004b; Roberts and Enright, 2004; Porter, 1998; Porter et al., 2004). An Australian Research Council study carried out in 2002-2003 and including face-to-face interviews with 150 Small to Medium Enterprises (SMEs) found that Chief Executive Officers 
(CEOs) and export managers focused less on the increase of export sales than on developing sustainable markets with reliable distribution channels (Hodgkinson et al., 2003). Other innovation-related export studies carried out by the author found that CEOs base their exporting success on a combination of factors. These include consistently high export intensity, a consistent increase in the number of export markets, building brands within key markets and a continued ability to service these markets. Sustainability is a key element in each of these criteria (Aylward, 2003; 2004a; Enright, 2001; Malmberg and Maskell, 2002).

Commentators such as Saimee et al. (1993) have found that, of the most innovative exporters surveyed within their study, 61\% considered their export activities to be a regular, ongoing (sustainable) part of their business. This compared with approximately $39 \%$ of what they refer to as the 'low innovative group' who only engaged in exporting on a sporadic basis. In addition, the 'innovative exporters' reported far higher levels of export intensity.

In an earlier empirical study of Brazilian exporters, Christensen et al. (1987) assessed factors of export sustainability by surveying firms over a six-year period. Drawing comparisons between continuing and ex-exporters, they developed profiles of sustainable exporters that included factors such as export intensity, foreign market penetration, distribution channels and CEO attitudes. While the study did not differentiate between firm size, and therefore was perhaps biased towards larger firm characteristics, it did provide a valuable template for further analysis, particularly with regard to specific export drivers and information networking.

Enright (2001) and Malmberg and Maskell (2002), through their studies of industry clusters, also highlight the importance of export sustainability in firm internationalisation. They argue that spatially concentrated clusters provide an environment conducive to higher levels of internationalisation through the networking of export associations, intra-firm networks, distributors and other critical supply chain elements.

The positive effect that operating within industry clusters has on SME export sustainability is an overriding concern of this paper. It will be investigated throughout a series of core export measures and management attribute case studies.

\section{Aims}

It is the intention of this paper to build on the above studies by:

- $\quad$ empirically assessing firm export activity within Australia’s most export intensive industry sector - the Australian wine industry

- $\quad$ profiling successful SME exporters using a matrix of core export indicators

- drawing on four 'best-practice' exporter models

- developing a set of common characteristics that best represents a sustainable exporter model. 


\section{Hypothesis}

The paper will also attempt to substantiate the hypothesis that a key characteristic of export success for SMEs is that they operate within industry clusters. Furthermore, the more developed and innovative the cluster, the more conducive it is to a firm's export success.

\section{Methodology}

Based on an extensive literature review and the author's previous studies, an empirical framework was established within which an exporter survey was designed. The survey was designed around core exporter measures, including internal/external drivers, export intensity, market penetration, diversification, increases in export sales over time, links between innovation and export activity and management attributes/attitudes. The purpose of the survey was to establish key characteristics of successful SME wine exporters.

A stratified, randomised sample was taken among wine SMEs within two distinctly different cluster types. These clusters were: South Australia, which represents the country's most innovative wine cluster; and New South Wales/Victoria, two states that represent 'organised', or substantially less developed clusters. In all, 100 SME firms were surveyed by phone, including 50 from the South Australian cluster and 50 from the New South Wales/Victorian clusters. Care was taken to ensure that the sample groups from which firms were selected displayed highly similar characteristics. An equal number of regions were selected within each state cluster and within these regions, firms in the same size and age categories. A Chi-Squared test was then conducted to verify the sample group's representation of the industry population. This confirmed that the sample group was indeed representative.

Data from the surveys was then entered into a spreadsheet so that patterns of measures could be grouped, variables could be ranked and cross-tabulations undertaken. These exercises were carried out for the surveyed firms as a single group and then by cluster type. For relevant sections of the paper, these data were then cross-matched with the author's previous databases on innovative measures grouped by firm size and cluster type.

In addition, four in-depth interviews were carried out with firms that the survey identified as 'best-practice' exporters. Two of these were selected from the South Australian cluster and two from the New South Wales/Victorian clusters. Interviews were carried out with either the CEO or Export Manager within each of these four firms, in an attempt to understand management attributes/attitudes of highly successful exporters, how these may differ from other exporters and how they match with other core export measures.

These data were then organised in an attempt to establish indicative profiles of successful SME wine exporters, with lessons for other industries and firms. 


\section{Findings}

Approximately 50\% of wine firms exported in the year 2003/2004. This compares to an Australian average participation rate for all industry sectors of just 4\% (Styles and Harcourt, 2002). Furthermore, in the period 1993/1994 to $2003 / 2004$ there was a $402 \%$ increase in the number of wine exporters, compared to an increase of only $143 \%$ in the actual number of firms established (Aylward and Turpin, 2003; Aylward, 2003). In 2004 Australian wine exports reached $\$ 2.4$ billion in value, with sales to the USA, now Australia's largest market, showing an increase of $39 \%$ over the previous year. ${ }^{3}$ These figures place the wine industry substantially ahead of any other Australian industry sector in terms of export activity.

Resources, infrastructure and productivity are not, however, distributed evenly within the industry. On a state-by-state basis, there are four main industry clusters - South Australia, New South Wales, Victoria and Western Australia. Many would argue that there are clusters within these clusters, but for the purposes of this paper, a state-level analysis is the more valid.

In terms of cluster type, South Australia represents what theorists commonly refer to as a highly developed, or 'innovative' cluster (Mytelka and Farinelli, 2000). It is inclusive, has numerous actors at a national and state level, has a high degree of vertical and horizontal integration and draws heavily upon the industry's research bodies. As a result, both inputs and outputs are closely interdependent and occur at high levels.

Of the 14 national industry associations, including regulators, national supplier groups, export councils, federations and research bodies, every one is in the South Australian wine cluster. Funding and intermediary agencies are also located there, as are the national training and education bodies. While South Australia is home to only $24 \%$ of the country's wineries, it accounts for $49 \%$ of production and $60 \%$ of the nation's exports (Winetitles, 2004). It has successfully integrated the core ingredients of viticulture, oenology and the organisational and marketing requirements into a highly evolved mix of innovation and export activity.

Victoria and New South Wales represent less developed or 'organised' clusters (Mytelka and Farinelli, 2000). While there is the same type of activity occurring, it is less intense, less integrated, involves fewer actors and is not as inclusive. A number of the industry bodies have only external influence on the cluster and thus their impact is significantly reduced. In addition to the reduced intensity of interaction, the core education and training providers are only vocational in nature. As a result of the above factors, inputs and outputs are also occurring at a lower level.

The following specific findings of the study closely reflect these above trends.

\subsection{Core Export Measure 1 - internal and external export drivers}

A key export measure, and one studied in detail by Saimee et al. (1993), is export initiative. This measure simply ascertains whether the exporting activity was initiated internally by the firm/CEO or whether the initiative was external, that is, whether the firm was approached by external parties such as distributors, importers or government agencies. An internal initiative indicates that the drive to export comes from the firm's management and that little or no help is sought in finding new markets, expanding 
current ones and establishing distribution channels. The internal initiative, therefore, is viewed as highly innovative behaviour. The external initiative is not viewed as a particularly innovative behaviour.

Of the 100 respondents to the question of whether exporting had been internally or externally driven, 63\% claimed that it had been internal. As a key measure of export innovation, this is an important finding, particularly as all respondents were SMEs, a group traditionally less export-oriented and less innovative in their export behaviour (Aylward, 2002; 2003). In comparison, across all Australian industry sectors, only 50\% of firms' export activities are reported as internally driven (Sytles and Harcourt, 2002).

These findings are reinforced by a number of the author's previous studies. In-depth interviews have found that even among micro and boutique wine firms, there was a relatively strong belief that exporting should be a firm-based initiative. Assistance from the Wine-makers Federation of Australia (WFA), the Australian Wine Export Council (AWEC) and other bodies, such as AUSTRADE and the Department of State and Regional Development (DSRD), were found to be useful in providing market information, contacts and quality controls. It was generally believed, however, that the drive into international markets, the development of sustainable relationships with distributors and agents and the long-term viability of an export status were the responsibility of the individual firm. It was also believed that such independence was critical to the continuing export viability of the industry as a whole and was what separated the Australian wine industry from the majority of its competitors (Aylward and Turpin, 2003; Aylward, 2002; 2003).

\section{Best practice It appears that 'internally' motivated exporters are more likely to} achieve higher levels of export activity.

\subsection{Core Export Measure 2 - export intensity}

A second core indicator of a firm's successful internationalisation is its export intensity. The study's survey respondents claimed an average export intensity (export sales as a percentage of total sales) of $31.6 \%$. Figures from the Australian Bureau of Statistics (ABS, 2003) show an average export intensity for all Australian firms across all sectors of just $18 \%$, with $63 \%$ of firms generating less than $10 \%$ of income from exports. This comparison places the study's SME wine firms significantly ahead of the national average. ${ }^{4}$

While the wine industry as a whole is known as a particularly export intensive sector, some clusters within the industry are more export intensive than others. For example, if we disaggregate the survey figures, respondents from the Victorian wine cluster averaged an export intensity rate of $26.5 \%$. New South Wales respondents recorded a similar rate of $27.3 \%$, but the South Australian cluster respondents recorded a substantially higher rate of $41 \%$.

The above results are in line with the author's previous studies and those from a number of other industry analysts (Porter, 1998; Porter et al., 2004; Mytelka and Farinelli, 2000; Roper and Love, 2002). It would appear from the differential shown between clusters for this indicator that there is a relatively strong association 
between export intensity and the cluster model. It is a differential that reinforces the hypothesis that the more developed the host cluster is, the higher the level of its firms' export activity.

Best practice The more export intensive wine SMEs are achieving an export intensity rate of at least $40 \%$.

\subsection{Core Export Measure 3 - increasing exports over time}

Respondents were next questioned about their export sales over a three-year period. Although the time period is relatively short, it does provide indications of future export sustainability. In total, $60 \%$ of the firms surveyed claimed that exports had increased over the past three years. Another 35\% claimed that exports had remained static and 5\% claimed that exports had dropped over the past three years. If we break these figures down by cluster type, an average $56 \%$ of firms within the New South Wales/Victorian clusters claimed that exports had increased, compared with 66\% from the South Australian innovative cluster. In addition, approximately $90 \%$ of all firms surveyed claimed to be regular exporters compared to only $1.8 \%$ of SMEs across all sectors, nationally (ABS, 2003).

An examination of the degree to which exports had increased over this three-year period reinforces the above trends. Overall, respondents claimed that exports had risen by an average of $21 \%$ per annum for the last three years. This compares with a national average across all industry sectors of approximately $9.5 \%$ per annum (ABS, 2003). Once again, export increase among respondents by cluster type is of more interest. The average per annum increase for firms within the New South Wales/Victorian wine clusters averages $14.8 \%$. This compares with the South Australian firms' claim of 32.2\%, or more than double the increase experienced by firms within the less developed clusters.

Such increases demonstrate that wine firms are experiencing more dramatic export growth than the average Australian exporter. Importantly, the growth also appears to be sustainable, remembering that approximately $90 \%$ of the surveyed firms are regular exporters and on average, they are experiencing significant export growth over a three-year period.

The figures also highlight the effect of different cluster environments. It appears that firms operating within the South Australian wine cluster are more likely to be self-initiated exporters, be more export intensive and experience substantially higher increases in exports over time.

Best practice Annual increases of approximately 30\% in export sales appear to be achievable for SME wine firms operating within innovative clusters.

\subsection{Core Export Measure 4 - international markets}

A fourth core indicator of export success is the ability of a firm to establish international markets and increase these markets over time. It is this element that is possibly the most difficult to achieve, particularly for SMEs. Entering the international market-place without the infrastructure, selling power, organisational resources, capital and established distribution networks of the larger firms is a commonly cited barrier across all industry 
sectors (Leonidou, 2004). Traditionally, SMEs have had difficulty moving from sporadic export status to that of a regular exporter (Hodgkinson et al., 2003). However, actively seeking out and establishing new markets requires significantly higher levels of organisation, logistical support and marketing. Yet, particularly in the past five years, Australian wine SMEs have achieved this and successfully followed their larger counterparts into an increasing number of markets.

For example, Australian wine industry data suggests that a decade ago, the number of export markets per firm, the vast majority (90\%) of which were SMEs, averaged 3.2. In 2004, there was an average of 6.4 markets per firm (Roper and Love, 2002; Winetitles, 2004). Disaggregating these figures by cluster type, we see the above indicator patterns replicated. The New South Wales/Victorian clusters recorded an average of 3.05 markets per firm in 1994 and 5.15 markets in 2004. By contrast, the South Australian cluster recorded an average of 3.3 markets in 1994 and 7.66 markets in 2004 (Aylward, 2004b; Roper and Love, 2002; Winetitles, 2004).

The study's survey respondents reflected the broader industry trend. Over a three-year period from 2000 to 2003, the New South Wales/Victorian respondents increased their markets from an average of 3.45 to 5.5 per firm. The South Australian firms increased their average number of markets from 5.89 to 7.96 per firm. In addition, both the directory data and surveys confirm that, as these firms mature in their internationalisation, there is an increase in the geographic diversity of these markets.

Looking at data from 1993-1994, we see an immature export industry, where the average firm has only several markets, each one of which is English-speaking and a traditional trade partner of Australia. These markets typically included the UK, the USA and New Zealand. As the industry's internationalisation has matured (although the UK and the USA typically remain dominant), the diversity of markets has risen to a healthy level, even among some of the micro exporters. Export associations, 'Brand Australia', operating within a 'learning environment' and substantially higher levels of interaction between firms, distributors and agents have provided the industry's SMEs with the confidence to extend their geographic activity. Thus, in 2004, the typical firm may claim Singapore, Hong Kong, Japan, Sweden, China, Fiji, Malaysia, Denmark, Thailand Slovakia or Vietnam among its export markets (Winetitles, 2004). It is a diversity that is being strongly encouraged by the industry and one that SMEs within both cluster models appear to be embracing.

Best practice It appears that the more successful SMEs are targeting five or more markets and, as their internationalisation practices mature, are also expanding into non-traditional and geographically diverse markets.

\section{Export-innovation linkages}

Porter (1998), Porter et al. (2004), Malmberg and Maskell (2002), and Enright (2001) are among a number of commentators who have drawn attention to innovation and export linkages within industry sectors. The author's previous studies have also highlighted an often intimate relationship between export intensity, growth and other innovative behaviours (Aylward, 2002; 2003; 2004b). 
Some of the current literature focuses on industrial clusters as the best examples of this creative milieu, in which innovative behaviour, including exporting, reaches its peak (Saimee et al., 1993; Mytelka and Farinelli, 2000; Malmberg and Maskell, 2002; Porter et al., 2004). It is argued, that as firms internationalise, their approach to information networks, new product development, process improvements, collaboration, uptake of research and marketing tends to become more sophisticated. Firms often need to upgrade production processes, develop new product brands, extend the existing product range, create more flexible distribution mechanisms and more sophisticated marketing. Clusters, it is argued, provide the most conducive environment for such innovative behaviour. They provide an environment in which higher levels of vertical integration are established, where a critical mass of firms, suppliers, research bodies, regulators, associated industries and government organisations cooperate and learn in ways that provide significant 'competitive advantage' (Porter, 1998). It is a competitive advantage that in the Australian wine industry, appears to induce, and be induced by, more intense exporting practices.

When respondents were questioned about the association between their own export and innovation activities, the cluster theory was clearly reinforced. Somewhat surprisingly, given previous indicators, only $50 \%$ of firms surveyed overall believed there was a strong association. However, when these data were disaggregated by cluster type, the patterns changed. In both New South Wales and Victoria, only 42\% (averaged) of respondents believed there was a strong innovation/export nexus in their operations. For South Australian firms, the figure was 66\%, supporting the hypothesis that, as clusters develop and become more integrated, the innovation/export nexus intensifies (Aylward, 2003; 2004b; Saimee et al., 1993).

Best practice The more successful SME exporters tend to associate their export activities more closely to their innovative activities. It appears from a number of empirical studies that this association is most pronounced within highly developed industry clusters.

\section{Management attributes and attitudes - case studies}

Among the more interesting aspects of the study were the in-depth interviews with identified 'best-practice' exporters. As mentioned, these firms ranked consistently ahead of the average in each of the core export measures. In terms of export intensity, increases in absolute exports, growth of exports over a three-year period, export motivation, as well as growth in number and geographic diversity of markets, these firms provided an industry template. Of the four firms identified, three were from the industry's highly developed cluster - South Australia and one from the less developed cluster - Hunter Valley, New South Wales. 
These firms possessed a number of critical elements that ensured their export success. Three clearly identified elements were:

1 management's attitude towards internationalisation

2 attention to individual markets

3 management's ability to exploit the natural advantages of operating within an industry cluster.

Each firm had entered the export process within the past ten years. Each had seen their exports grow consistently both in real terms and as a percentage of total sales (export intensity). In varying degrees they had increased the number of export markets and their markets' geographical diversity. Interestingly, three of the four also claimed to have increased their domestic market share over the past three years. All four firms expected to increase export sales by between $25 \%$ and $40 \%$ per year over the next three years. They also expected the number of markets to grow by between two and four each year, but did not intend to push beyond this rate. A higher rate was believed to be inversely related to sustainability. As one interviewee stated, "It is not so much about the rate of growth, as the consistency of growth."

The firms varied in size and experience. They varied marginally in sales growth rates and to a larger extent in their products' targeted price points. Their approach to exporting, however, was remarkably similar.

\subsection{Attention to markets}

In each case, either the CEO, the export manager and/or senior wine-maker spent a considerable amount of time attending to individual markets, not attempting to enter new markets until they were completely satisfied with existing operations. Specifically, the 'attention to individual markets' included very regular (at least two times per year to each market) trips to visit distributors, agents and marketing outlets, whether they be off-licence bars, liquor stores, restaurants or supermarkets. Without exception, management of these firms believed that a trusting, long-term relationship with their distributors and agents were critical to their success. At the same time, however, their trips were also a way of ensuring that their agents were providing their products with either exclusive or core marketing and promotion. They deliberately chose agents with limited clients in order to provide their own products with maximum attention and exposure.

In addition, they ran fairly regular 'road-shows' in each market, spending two to three weeks in a core city or region, running and attending wine shows and promotional activities. They also engaged in national, regional and individual branding activities. As one export manager claimed, "The pressure of staying on top is relentless. There is no rest, no complacency. Those who take their market for granted quickly fall behind or lose the market altogether." 


\subsection{Motivation behind export drive}

In each of the firms interviewed, the motivation to export had clearly originated from management and/or the owner. This internal motivation replicates the best practice model identified in the study's broader survey. One firm strongly believed that the export market was required for continued growth and to this end, deliberately targeted those markets it believed to be the most easily accessible and lucrative for their brands. It also targeted very specific price points that provided high margins in each of these markets. The strategy appears to be working. For the other three firms, exporting was always integral to the agenda. In each case, the CEO had outlined a plan that from its inception included an evolutionary approach to internationalisation as part of the firm's overall objectives.

\subsection{Exporting methods}

While two of the firms began exporting on a sporadic basis, relying on direct exporting methods, all now exclusively use distributors and agents. The preferred method among these firms was to appoint distributors for each individual market, establish a strong relationship between distributors and agents and, as one CEO expressed it, "constantly tweak the strategy to ensure all parties are happy and we are not simply promoted as a firm within an export package, but individually!”

The other common element in this approach was the length of time each agent had been with the firm. In all cases Management placed great importance on close personal relationships with their agent(s) developed over many years. They believed the agent was critical to their success and that the relationship required constant nurturing.

\subsection{Key drivers of export success}

Each of the four 'best-practice' firms had very definite strategies for increasing export sales over time. These included:

- increasing export intensity to between $50 \%$ and $60 \%$ over the next three years

- creating sustainability in terms of sales and number of markets

- trialing non-traditional but growth oriented markets, such as China, India, Thailand, Japan and regions of Scandinavia

- creating individual brands based on regionality and higher price points

- targeting the growth in off-licence distributors

- matching brands and style to specific markets.

In addition, they believed that there were a number of fundamental areas in which their firm behaved differently from the average wine exporter. It was generally agreed that consistency of supply, product and marketing was essential to success. Each firm ensured that this consistency could be maintained for each new market. One of their main concerns for the industry in general was that, among the smaller exporters, inconsistent 
supply and variable marketing approaches within key markets undermined the integrity of the Australian brand. Regulations needed tightening in these areas in order to maintain the industry's reputation.

Attention to detail in terms of shelf placement, appropriate price points, market image, consumer-driven branding and presentation were also considered integral to a firm's successful export activities. This, it was agreed, came primarily with experience.

A final difference between these firms and the average wine exporter was what one CEO termed their 'ability to react to changing and evolving markets'. There was general consensus among the four that within an increasingly competitive export environment, with increased product and price sensitivity, the ability to respond to a fickle consumer was vital. New World producers have built their success on their consumer-driven approach to marketing (PMSEIC, 1999). Servicing this approach required constant monitoring of competitors, new price points, shelf placement, and wine awards. Also required was the ability to replace or change branding, to introduce a new region-specific style, or discontinue a faltering style. Each firm believed that it is this type of attention that creates true export sustainability.

\subsection{Operating within clusters}

Reinforcing data from the broader survey, each of the four firms strongly believed that operating within an industry cluster held significant advantages for their export activities. The firm within the less developed New South Wales cluster believed that its advantages would be magnified if it were located within the South Australian cluster. Two of the three South Australian cluster firms agreed with this sentiment, while the third firm believed it could achieve the same results in a less developed cluster such as New South Wales.

Specifically, the four firms identified elements such as more intense information flows, greater access to research, closer proximity to national suppliers and regulators, a more developed supply chain, brand identification and proximity to the HQ of the industry's major firms. As one export manager stated:

"It is a complex relationship, and a lot of smaller firms are critical of the big players, but we have to remember that to a large extent we are here because of them. We have ridden on their backs into each of the major export markets and they have provided the reputation that we now enjoy."

\section{A snapshot of successful exporter characteristics}

In order to help digest the above characteristics Figure 1 below provides a visual snapshot of characteristics most common to successful exporters. It should be noted that successful exporters also have other significant characteristics not mentioned in this paper. Conversely, many successful exporters do not incorporate some of those characteristics mentioned. What this paper does aim to provide, however, is an overview of characteristics common to those identified as sustainable exporters. 


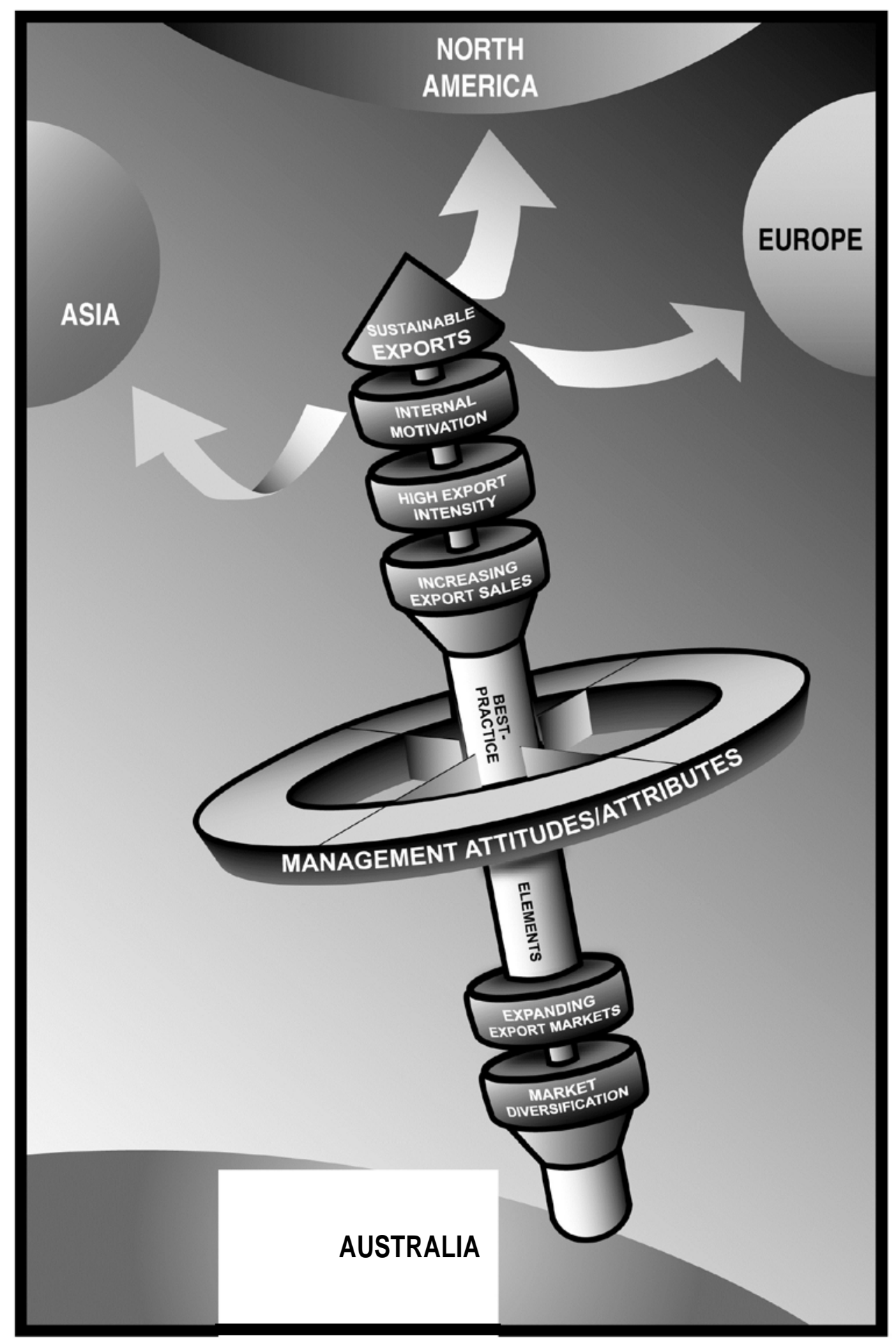




\section{Concluding remarks}

The internationalisation process for most firms is one of complexity. It involves a myriad of industry-specific, market-specific and firm-specific elements that impact at different times and in different ways on a firm's export life cycle. What works in one industry or market may not in another. What worked well for a particular firm five years ago may no longer produce the same results. The process is a constantly evolving animal that requires a firm's continual attention, flexibility, planning and quality control.

This paper does not attempt to provide an export template. Such a tool is not possible. What the paper does attempt to do is highlight or profile common characteristics of successful SME exporters within a particularly successful export industry. As such, lessons may be provided for firms in general, and for firms within New World wine industries in particular.

Inherent in any 'lesson' drawn from the paper is the focus on export sustainability. Empirical data presented throughout the paper reinforce the notion that 'success' in exporting is not simply export intensity, the rate at which export sales and markets increase over time, or management attributes alone. Rather, it incorporates all of these characteristics within the sustainable internationalisation of a firm's activities.

Finally, a central theme of the paper has been the 'competitive advantage' gained from operating within highly developed industry clusters. Both survey and industry data show clearly that those SMEs operating within the South Australian wine cluster are more export intensive, increase their export sales at a higher rate and in a more sustainable fashion and export to more markets. They are also more geographically diverse and more closely associate their exports with innovative activities. Clusters provide SMEs with the resources, vertical integration, infrastructure, research and education, branding, marketing, networking and economies of scale that they simply cannot access in a more isolated environment. The more highly developed the cluster, the more advantageous the operating environment and the greater the translation of these advantages into a firm's export activities.

\section{Acknowledgement}

The author would like to acknowledge the technical assistance of Robert Hood in preparing this paper and for designing and producing Figure 1.

\section{References}

Anderson, K. (2000) Export-Led Growth: Lessons from Australia's Wine Industry, RIRDC Publication No. 00/52, University of Adelaide.

Australian Bureau of Statistics (ABS) (2003) A Portrait of Australian Exporters 2003, Ref. no. 8154.0, Canberra: Australian Government Printer.

Aylward, D. (2002) 'Diffusion of R\&D within the Australian wine industry', Prometheus, Vol. 20, No. 4, pp.351-366.

Aylward, D. (2003) 'Mapping Australia’s wine exports', Wine Industry Journal, Vol. 18, No. 6, pp.68-72. 
the Australian wine industry', Prometheus, December, forthcoming.

Aylward, D. (2004b) 'Wine clusters equal export success', The Australian and New Zealand Grapegrower and Winemaker, August, No. 487, pp.105-107.

Aylward, D. and Turpin, T. (2003) 'New wine in old bottles: a case study of innovation territories in "new world” wine production', International Journal of Innovation Management, Vol. 7, No. 4, pp.501-525.

Beeston, J. (1994) A Concise History of Australian Wine, London: Allen and Unwin.

Christensen, C.H., da Rocha, A. and Gertner, R.K. (1987) 'An empirical investigation of factors influencing exporting success of Brazilian firms', Journal of International Business Studies, Vol. 18, No. 3, pp.61-77.

Darling, J.R. and Taylor, R.L. (2003) 'Successful exporting by the small business firm: keys for strategic decision-making', The Journal of Contemporary Business Issues, Vol. 11, No. 1, pp.1-12.

Enright, M.J. (2001) 'Regional clusters and multinational enterprises: independence, dependence, or interdependence', International Studies of Management and Organisation, Vol. 30, No. 2, pp.114-138.

Faith, N. (2002) Liquid Gold: The Story of Australian Wine and Its Makers, Pan Sydney: Macmillan.

Hodgkinson, A., Iredale, R., McPhee, P., Vipraio, P.T. and Aylward, D. (2003) Internationalisation, Information Flows and Networking in Rural and Regional Firms: Final Report and Policy Recommendations, Wollongong: University of Wollongong Press.

Leonidou, L.C. (2004) 'An analysis of the barriers hindering small business export development', Journal of Small Business Management, Vol. 42, No. 3, pp.279-302.

Malmberg, A. and Maskell, P. (2002) 'The elusive concept of localization economies: towards a knowledge-based theory of spatial clustering', Environment and Planning A, No. 34, pp.429-449.

Moen, O. and Servais, P. (2002) 'Born global or gradual global? Examining the export behavior of small and medium-sized enterprises’, Journal of International Marketing, Vol. 10, No. 3, pp.1-7.

Mytelka, L. and Farinelli, F. (2000) 'Local clusters, innovation systems and sustained competitiveness', Discussion Paper Series, The United Nations University, Institute for New Technologies.

Ogunmokun, G. and Wong, J. (2004) 'Determinants of marketing adaptation/globalisation practices of Australian exporting firms', World Review of Science, Technology and Sustainable Development, Vol. 1, No. 1, pp.81-92.

Porter, M. (1998) 'Clusters and the new economics of competition', Harvard Business Review, Vol. 76, No. 6, pp.77-90.

Porter, M., Ketels, C.H.M., Miller, K. and Bryden, R. (2004) 'Competitiveness in rural US regions: learning and research agenda’, Report, Harvard Business School.

Prime Minister's Science, Engineering and Innovation Council (PMSEIC) (1999) Report to PMSEIC, Fourth meeting, Canberra, November.

Roberts, B.H. and Enright, M. (2004) 'Industry clusters in Australia: recent trends and prospects', European Planning Studies, Vol. 12, No. 1, pp.99-121.

Roper, S. and Love, J. (2002) 'Innovation and export performance: evidence from the UK and German manufacturing plants', Research Policy, Vol. 31, pp.1087-1102.

Saimee, S., Walters, P.G.P. and DuBois, F.L. (1993) 'Exporting as an innovative behaviour: an empirical investigation', International Marketing Review, Vol. 10, No. 3, pp.1-10.

Spence, M.M. (2003) 'Evaluating export promotion programmes: UK overseas trade missions and performance’, Small Business Economics, Vol. 20, No. 1, pp.2-6. 
Styles, C. and Harcourt, T. (2002) 'Stairway to (export) heaven', AUSTRADE Speech, Press release.

Voerman, J.A. (2003) The Export Performance of SMEs, Ridderkerk: Labyprint Publications, Offsetarukkerij Ridderprint BV.

Wang, G. and Olsen, J. (2002) 'Knowledge, performance, and exporter satisfaction: an exploratory study', Journal of Global Marketing, Vol. 15, Nos. 3-4, pp.39-64.

Winetitles (2004) The Australian and New Zealand Wine Industry Directory, Adelaide.

Winetitles (2005) The Australian and New Zealand Wine Industry Directory, Adelaide.

Wolff, J.A. and Pett, T.L. (2000) 'Internationalization of small firms: an examination of export competitive patterns, firm size and export performance', Journal of Small Business Management, Vol. 38, No. 2, pp.34-47.

Yetton, P., Davis, J. and Swan, P. (1991) 'Going international: export myths and strategic realities', Australian Journal of Management, Vol. 16, No. 2, pp.229-237.

\section{Notes}

1 Wine Institute, http://www.wineinstitute.org/communications/statistics/exports03.htm.

2 Wines of South Africa, http://www.wosa.co.za/statistics.asp.

3 The Advertiser, South Australia, 20 April 2003.

4 The latest figures available for export activity from the Australian Bureau of Statistics (ABS) are 1998 figures. Although these are not as recent as those used for the wine industry, the differences are stark enough that they may be interpreted as highly indicative. 